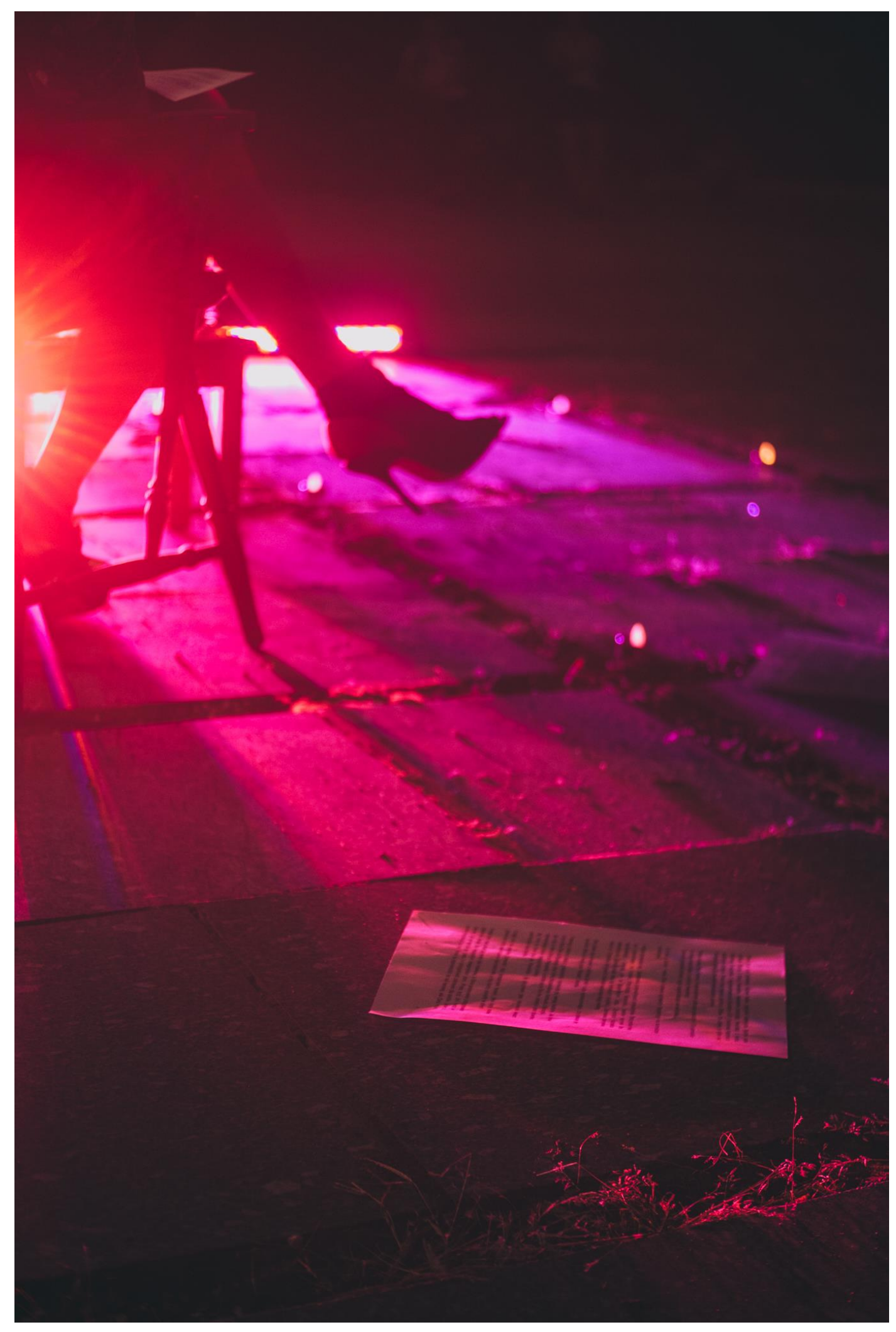

Liliana Piskorska, Sosna z sześcioma rękami, dokumentacja performance, Wzgórze Słowiańskie we Wrocławiu, 2020, fot. Wojciech Chrubasik 


\section{Sosna z sześcioma rękami: wstęp}

https://doi.org/10.51897/interalia/FLUJ4810

Mathias Foit

Freie Universität Berlin

Niezwykłą historię hrabiny Diny Almy de Paradedy, która ostatnie tygodnie życia spędziła w Breslau, jak nazywano wówczas leżący w obrębie Cesarstwa Niemieckiego Wrocław, świat niemieckojęzyczny poznał za sprawą Jensa Doblera, który w 2010 r. ponownie wydał i opatrzył posłowiem napisaną ponad 100 lat wcześniej powieść Waltera Homanna pt. „Tagebuch einer männlichen Braut” („Pamiętnik męskiej narzeczonej"), inspirowaną losami de Paradedy. W tym to posłowiu można odnaleźć zestawienie nielicznych pewnych faktów, przeplatanych z niewyjaśnionymi tajemnicami i domysłami dotyczącymi życia samozwańczej komtesy. Nie wiadomo, czy urodzona jako Alfred (bądź Alfredo) H. (a może P.?) Dina faktycznie miała szlacheckie pochodzenie; kim był jej biologiczny ojciec i czy naprawdę był hiszpańskim konsulem w Rio de Janeiro; jaka relacja łączyła ją z jej ojczymem, niemieckim lekarzem, który poślubił pewną owdowiałą Brazylijkę; czy ukochany Diny znał jej sekret, a zaręczyny zerwał tylko ze względu na reakcję i naciski ze strony jego rodziny; i wreszcie, kto i dlaczego złożył donos na hrabinę. Pewnym jest natomiast, że tragiczna historia jednej z pierwszych znanych z imienia i nazwiska osób trans* w Europie Środkowej poruszyła opinię publiczną nie tylko w Niemczech, ale i m.in. w Stanach Zjednoczonych czy Nowej Zelandii. Oprócz licznych artykułów prasowych, nierzadko podających sprzeczne informacje i przez to utrudniających dokładną rekonstrukcję tamtych wydarzeń, w druku pojawiły się też co najmniej dwie powieści inspirowane losami "męskiej narzeczonej" z Wrocławia, w tym właśnie utwór Homanna, i to już w parę miesięcy po skandalu wywołanym jej samobójczą śmiercią, co niewątpliwie świadczy o medialnej nośności i popularności tej historii. Ja sam natknąłem się na nią w trakcie badań do pracy doktorskiej na temat życia osób nie heteronormatywnych na przełomie XIX i XX wieku oraz w okresie międzywojennym na byłych terenach niemiećkich, obecnie należących do Polski.

Choć od wspomnianych wydarzeń minął ponad wiek, w tym samym Wrocławiu, a także szerzej w całej Polsce, osobom nieheteronormatywnym - w szczególności zaś osobom trans* - niewiele łatwiej jest funkcjonować w przestrzeni publicznej. Wciąż spotyka je niezrozumienie, brak życzliwości, a coraz częściej (i z coraz bardziej zatrważającą intensywnością) - agresja, nienawiść, przemoc. Historia Diny, dla której życie w zgodzie ze swoją tożsamością było cenniejsze niż życie samo w sobie, nabiera szczególnego znaczenia dzisiaj, w 2020 roku, w którym kolejne osoby nieheteronormatywne, zwłaszcza nastolatki, zadają sobie śmierć, nie mogąc znieść atmosfery zaszczucia i wykluczenia, której są poddane z wszystkich stron. Znamienne jest również to, że odczytanie tekstu baśni na Wzgórzu Słowiańskim przez drag queen Twoją Starą miało miejsce 8 sierpnia, dzień po brutalnym stłumieniu demonstracji przeciw aresztowaniu aktywistki i współzałożycielki "Stop Bzdurom" Margot i dalszych zatrzymaniach prawie 50 osób biorących udział w akcji protestacyjnej. W świetle tych wydarzeń 
w tekście Liliany Piskorskiej jeszcze bardziej wybrzmiewa sprzeciw wobec prób wymazania ze świadomości społecznej, a czasami wręcz unicestwienia osób nieheteronormatywnych w Polsce. To głos domagający się uznania ich równoprawnej egzystencji oraz poszanowania należnej im wolności i szacunku. Wspomniany performens i dokumentująca go wystawa, którą można było obejrzeć przez cały sierpień 2020 w Złotym Kiosku - wyjątkowej, bo posiadającej wymiary 2,5x2,5×2,5 m galerii sztuki jest częścią programu kulturalnego organizowanego z okazji 50. rocznicy Sympozjum Plastycznego Wrocław '70, które dodatkowo upamiętnia wystawa "Nowa normatywność" w Muzeum Współczesnym Wrocław. 